\title{
Integrated Inventory Management Control Framework
}

\author{
H. R. Ganesha ${ }^{1}$, P. S. Aithal ${ }^{2}$, \& P. Kirubadevi ${ }^{3}$ \\ ${ }^{1}$ Chief Executive Officer - Consulting Division, Gramss Retail Trading Private Limited, \\ Bengaluru - 560078, India and Post-Doctoral Research Fellow, College of Management \& \\ Commerce, Srinivas University, Mangalore - 575001, India. \\ OrcidID: 0000-0002-5878-8844; E-mail: hrganesha@yahoo.co.in \\ ${ }^{2}$ Vice Chancellor, Srinivas University, Mangalore - 575001, India. \\ OrcidID: 0000-0002-4691-8736; E-mail: psaithal@gmail.com \\ ${ }^{3}$ Head of Category Management and Sourcing, Actoserba Active Wholesale Private Limited \\ (Zivame), Bengaluru - 560038, India. \\ OrcidID: 0000-0003-2291-8448; E-mail: spkirubadevi@yahoo.com
}

Area/Section: Business Management.

Type of the Paper: Research Paper.

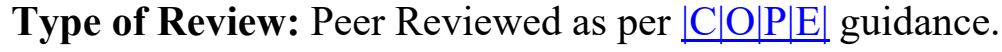

Indexed in: OpenAIRE.

DOI: $\underline{\text { http://doi.org/10.5281/zenodo.3775868. }}$

Google Scholar Citation: $\underline{\text { IJMTS. }}$

\section{How to Cite this Paper:}

Ganesha, H. R., Aithal, P. S., \& Kirubadevi, P. (2020). Integrated Inventory Management Control Framework. International Journal of Management, Technology, and Social Sciences (IJMTS), 5(1), 147-157. DOI: http://doi.org/10.5281/zenodo.3775868.

International Journal of Management, Technology, and Social Sciences (IJMTS)

A Refereed International Journal of Srinivas University, India.

(C) With Authors.

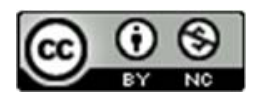

This work is licensed under a Creative Commons Attribution-Non-Commercial 4.0 International License subject to proper citation to the publication source of the work.

Disclaimer: The scholarly papers as reviewed and published by the Srinivas Publications (S.P.), India are the views and opinions of their respective authors and are not the views or opinions of the SP. The SP disclaims of any harm or loss caused due to the published content to any party. 


\title{
Integrated Inventory Management Control Framework
}

\author{
H. R. Ganesha ${ }^{1}$, P. S. Aithal ${ }^{2}$, \& P. Kirubadevi ${ }^{3}$ \\ ${ }^{1}$ Chief Executive Officer - Consulting Division, Gramss Retail Trading Private Limited, \\ Bengaluru - 560078, India and Post-Doctoral Research Fellow, College of Management \& \\ Commerce, Srinivas University, Mangalore - 575001, India. \\ OrcidID: 0000-0002-5878-8844; E-mail: hrganesha@yahoo.co.in \\ ${ }^{2}$ Vice Chancellor, Srinivas University, Mangalore - 575001, India. \\ OrcidID: 0000-0002-4691-8736; E-mail: psaithal@gmail.com \\ ${ }^{3}$ Head of Category Management and Sourcing, Actoserba Active Wholesale Private Limited \\ (Zivame), Bengaluru - 560038, India. \\ OrcidID: 0000-0003-2291-8448; E-mail: spkirubadevi@yahoo.com
}

\begin{abstract}
The concept of minimum display quantity (MDQ) is unavoidable in brick-and-mortar retailing format owing to which, retailers need to ensure a minimum level of inventory displayed at each store irrespective of the revenue or inventory turns generated by a particular store. It is observed that majority of bricks-and-mortar retailers in India assume;(a) existing inventory management system is ideal to their store, (b) software solutions record accurate inventory movement, (c) involving store management team in inventory related decision making is risky/biased and most importantly (d) loss of sale due to stockouts is inevitable. Such assumptions and widely followed practice have created a predisposition and mindset in store managers and they believe that their store delivers revenue and profit to the best of its potential with the inventory which is made available to them through existing inventory management system and we cannot avoid a number of instances consumers are unsatisfied due to stockout situations. In this research, we have analysed the existing decision-making process and control systems related to inventory management of a select retailer, attempted to design a new framework and applied the same through an experiment to evaluate the change in (a) overall store profitability and (b) inventory related key performance indicators.
\end{abstract}

Keywords: Brick-and-mortar store; Offline store; Physical store; Salespeople; Salesperson; Sales Personnel; Inventory Management; Inventory Turns; Stock Cover; Stock Turns; Inventory Management Control.

\section{INTRODUCTION :}

Inventory is one of the most important costs in retailing which holds a significant share of the overall retailing cost structure. Even though inventory cost is variable in nature, due to its carrying cost nature inventory becomes an even more important aspect of retailing which has a direct impact on overall store and retailing profitability. Multi-category and multi-branded retail stores catering to multiple life-stage needs of a consumer comprise of many products/categories which are designed to serve the specific needs of consumers. Most of the retailers, classify these products into different sections either based on consumer needs (demand side) or product's behaviour (supply side) or visual appeal (communication side) or consumer life-stage (solution side) and this classification is known as categories. Each of these categories includes multiple sub-categories and each subcategory is comprised of multiple brands, models, colours, and SKUs. Every product/category/brand in the entire store's product offering plays an important role with respect to consumers and retailers. It is imperative to note that, the understanding of the 
role played by a particular product/category/brand might not be the same among consumers, retailers and sales personnel. What is really important and of significant essence is that every employee in the retailing business whether belonging to central office or store is familiar with each of these product/category/brand's roles in relation to consumers' needs and align their inventory management systems and inventory related decision controls which could possibly help the retailer to enhance optimal utilization on inventory thereby enhancing (a) overall consumer satisfaction, (b) overall store profitability and (c) retailing company's profitability along with efficient cash-flow. Unfortunately, it is not possible for any one department or function in the retail company to have perfect/ideal level of knowledge/expertise of inventory management suitable for every store spread across many locations and at the same time retailers cannot risk giving 100 percent control over inventory related decision making to store management team just because they would localize the inventory requirements due to the financial nature of inventory. For many years it has been debated among retailing management researchers about, what is the ideal inventory management system, who should control it, who should own the decisions. Few have suggested to make use of software solutions and others have recommended to adopt different techniques available in inventory management.

\section{LITERATURE REVIEW :}

Salmon (1989) [1] argues that it is no more just merchandising, which is important for successful retailing, what is becoming more and more important nowadays are other aspects of store operations which include various other aspects including inventory management. Raman et al. (2001) [2], in their study, reported that the accuracy level of inventory available in the store is significantly poor and this was attributed to issues with inventory replenishment systems and inventory planning methodology. Wanger (2002) [3] argues that because of various data related issues including inventory accuracy levels, many fail to implement the automated replenishment system and strongly recommend that different replenishment tools must be applied in relation to real-time inventory issues. Kaizers et al. (2003) [4] studied the relationship between store managers decisions on inventory planning and overall store profitability whereby they found that owing to complexities store managers fail to take appropriate decisions related to inventory management. Corsten and Gruen (2003) [5] studies the relationship between stockouts and overall store revenue, confirms that the relationship is significant and the key reason for such stockouts is the inventory management system that the store has adopted. DeHoratius and Raman (2003) [6] suggest that the retailer need to understand the root causes for operational deficiencies, regularly identify and correct the deficiencies through audits and most importantly make use of systems by integrating inventory management system with software solutions. Ton and Raman (2004) [7] argue that the number of instances of inventory being available in the store's backroom but not on the shelves significantly increases as the variety in categories/brands/products/models/SKUs increases in the assortment. Van Donselaar et al. (2006) [8] have found that the store management team regularly made modifications to the automatic replenishment system to accommodate changes in demand which ensure optimal utilization of systems with regular human intervention.

James L. Hesket et al. (1997) [9], argue that the profitability is significantly derived from consumer loyalty which is strongly linked to a) internal service quality and b) satisfied and productive service employee. The service-profit chain model created in their work holds true even after globalization, liberalization and digitization of the retail market. Inventory cannot treat as one of the key aspects of retailing in isolation. The level and type of inventory also impact the satisfaction and productivity levels of sales personnel.

In the past, various indicators which can indicate a retail sale in relation to quality and level of sales personnel involvement have been studied and analysed by many researchers. Most important indicators were (a) the amount and quality of time 
spent by the sales personnel with the consumer (Davis. H.L. et al. (1972) [10]), (b) variety of products/SKUs/models being showcased by the sales personnel to consumer (Dawson et al. (1992) [11]), (c) level of information being collected by the sales personnel on consumer needs directly from the consumer (Sharma. A. (2001) [12]), (d) sales personal's efforts to understand the consumer brand preference and showcasing products/SKUs/models in relation to the preference (Pettijohn. C.E. et al. (2002) [13], (e) sales personnel's capability to explain the features of products showcased to consumers and their confidence level while explaining the differentiation among a variety of products showcased (Aggarwal. P. et al. (2005) [14]) and (f) the range of products/SKUs/models showcased by the sales personnel in relation to price and utility expected by the consumer (Davis. D. D. (2008) [15]). All these findings are affirmative to the fact that the sales personnel's engagement with the consumer in real-time significantly influence consumer's purchase decision directly and it is imperative that store management team is also involved in inventory related decision making.

Ganesha, H.R. et al. (2020) [16], conducted a sales personnel centric experiment by changing the sales personnel's performance measure from output driven to input driven measures and found that the input driven measures were all helping the sales personnel to understand the role of each product; be it essential, non-essential, high priced, low priced and so on and indirectly these measures were pushing them to focus on just the consumer's needs, consumer's lifetime value rather all the time thinking about just one transaction.

Ganesha, H.R. et al. (2020) [17], carried out a sales personnel centric experiment wherein they attempted to decentralize the discounting process by empowering sales personnel to decide on the type and level of discount to be offered to consumer found that, it is not just the discount level, type, duration, coverage and advertising discount offer which is important to attract more consumers and increase their intent to purchase more, what is also very important is (a) how does the sales personnel who is dealing with the consumer directly and has real-time insights about consumer's intent, needs and attitude towards a particular purchase activity communicate available discount offers to consumers with confidence, (b) does he/she believes in a particular discount offer and (c) can he/she convince the consumer about the benefits of discount offers which are not real-time. Both these experiments in a way indicate that sales personnel need to be considered as the most important last-mile communication delivery personnel who has the capability of creating a positive perception about the retailer.

Ganesha, H.R. et al. (2020) [18], carried out a sales personnel centric experiment in which they had implemented a need-based sales pitch technique. The results were affirmative of the fact that the level and quality of interaction between sales personnel and consumers is important to understand the consumer life-stage which in turn helps the sales personnel to correctly identify the real-time need of the consumer and suggest relevant products to be purchased. This in a way raises questions about are the stores run with an optimal number of sales personnel all the time that too especially during peak sales hours.

In the existing literature, we were trying to find a framework which we would apply and evaluate if the framework is able to answer our key research questions in the Indian context. But we could not find a model/framework with which we can answer our research questions such as (a) can we believe that the existing centralized inventory management control system is appropriate and optimal?, (b) can we believe that the existing system ensured timely delivery of required inventory adequately on time?, (c) can't we reduce the number of instances sales personnel are not able to find the right product in front of a consumer and finally ending up in a loss of sale?, (d) can't we reduce the number of unsatisfied consumers due to unavailability of relevant stocks when they have already made a purchase decision and put all the efforts to come over to the store?, (e) if we cannot believe in the existing inventory management system, then what is the way in which we can understand the ideal way of managing the inventory related decision making which shall probably ensure minimal stockout 
situations. Thus, we decided to understand the existing policies and methodology of inventory related decision making, modify the existing system, experiment, and evaluate the results. Based on results integrate various aspects and teams involved in inventory related decisionmaking processes and create an integrated framework.

\section{OBJECTIVES :}

Key objectives of this research were to;

(a) understand the change in overall store profitability by decentralizing the inventory management system across;
a. control group
b. experimental group
c. pre-test period
d. post-test period

(b) draw insights from the experimentation.

\section{METHODOLOGY :}

Stage I: One of the organized brick-and-mortar retailers in India was selected who is having stores all over India across (a) mall stores, (b) high-street stores, (c) neighbourhood stores, (d) tier 1,2 and 3 cities, (e) offering multiplecategories and multiple-brands serving different consumer life-stage needs at mid to high price positioning catering to pregnant women, new moms, babies, infants and kids up to 8 years. 15 percent of stores were selected to undergo experimentation and others were treated as control group stores.

Stage II: Quantitative data for all the stores were collected prior to experimentations (pre-test). An open-ended personal interview was conducted for randomly selected (convenience sampling) sales personnel across experimental and control group stores along with central teams managing category, retail planning, supply chain, finance and strategy to understand their understanding and attitude towards existing inventory management systems.

Stage III: Continuous training was conducted to all the store management team of the experimental group including store managers, area sales managers, territory managers, regional managers and the national sales head along with central retail planning team over a period of 30 days prior to applying the new framework to impart knowledge about the new system, its pros and cons, implementation methodology and importantly the key goal of the experimentation. Post-training the new system was implemented across all the stores selected for experimentation over a period of three months (experimental phase).

Stage IV: Results obtained during the experimentation stage (post-test) analysed using appropriate statistical methods and compared with the pre-test period.

Stage V: The findings from this experimentation were compared with pre-test across experimental and control groups.

Stage VI: In this stage, insights and inferences from the research findings were used to propose a way forward for brick-and-mortar retailers to enable them to decide on the decentralization level for inventory management required to enhance their overall store profitability.

\section{INTEGRATED INVENTORY MANAGEMENT FRAMEWORK :}

During the direct interview with the store team and along with central teams managing category, retail planning, supply chain, finance, and strategy teams we noted that the inventory management was centralized and majorly controlled by category management and retail planning teams. All decisions related inventory was primarily controlled by central management teams as listed in table 1.

Majority of central team members assume that the centralized control over inventory related decisions are (a) able to deliver optimal results as they have been following this methodology since a long time, (b) they are able to understand consumer buying behaviour based on store sales data, (c) they know the local/store level competition, (d) all stores must behave similarly as they are all under the same retail store brand name, (e) consumers expectations are well within the category/brand/product assortment available inside the store, (f) store management team has lesser knowledge of inventory management, (g) store do not think of the overall retailer image when they request for specific inventory, $(h)$ store team is poor in understanding supply chain challenges and most importantly, (i) control over 
inventory level is efficient when managed by central teams. On the other side majority of store team members expressed their feelings exactly opposite to what central teams have assumed. This inverse understanding over inventory management control led us to experiment a completely opposite inventory management control system which is a decentralized one. We attempted to decentralize most of the inventory related decisions and experimented (experiment 1) the same over a period of three months. Key changes in the decentralized inventory management system are listed in table 2;

Table 1: Control (centralized) over inventory related decisions between central team and store teams.

\begin{tabular}{|l|c|c|}
\hline Decisions & $\begin{array}{c}\text { Central } \\
\text { Management } \\
\text { Team }\end{array}$ & $\begin{array}{c}\text { Store } \\
\text { Management }\end{array}$ \\
\hline Team
\end{tabular}

Table 2: Control (decentralized) over inventory related decisions between central team and store teams.

\begin{tabular}{|c|c|c|}
\hline Decisions & $\begin{array}{c}\text { Central } \\
\text { Management }\end{array}$ & $\begin{array}{c}\text { Store } \\
\text { Management }\end{array}$ \\
\hline & Team & Team \\
\hline Category Assortment & $x$ & $\checkmark$ \\
\hline Brand Assortment & $x$ & $\checkmark$ \\
\hline Product Assoitment & $x$ & $\checkmark$ \\
\hline Price Lining & $x$ & $\checkmark$ \\
\hline Pricing & $x$ & $\checkmark$ \\
\hline Design and Development & $\checkmark$ & $x$ \\
\hline Product Launch Timing & $x$ & $\checkmark$ \\
\hline Visual Merchandising & $x$ & $\checkmark$ \\
\hline Product Allocation to Stores & $x$ & $\checkmark$ \\
\hline Quantity per Product Allocation to Stores & $x$ & $\checkmark$ \\
\hline Product Replenishment & $x$ & $\checkmark$ \\
\hline Product Replacement & $x$ & $\checkmark$ \\
\hline Product Ordering with Suppliers & $\checkmark$ & $x$ \\
\hline Product Ordering with Warehouse & $x$ & $\checkmark$ \\
\hline Product Discounting & $x$ & $\checkmark$ \\
\hline Product Promotions & $x$ & $\checkmark$ \\
\hline Product Purchase Budget & $x$ & $\checkmark$ \\
\hline Inventory Carrying Threshold & $\checkmark$ & $x$ \\
\hline
\end{tabular}

Results of decentralization of control over inventory related decision have shown a 39 percent increase in total purchase value, but it failed to show any significant increase in conversions and revenue which was expected to increase as based on the exploratory study it was noted that store teams understand consumers, consumer requirements and local./store level competition better than the central teams, hence, if the inventory related decisions are made by them the probability of higher conversion and revenue is higher. The significant finding of the experimentation was that the overall store profitability decreased by 2.490 times in comparison to centralized inventory management control system and most importantly the category/brand/product/price assortment was not even/consistent across different stores which could possibly affect the overall retailer image among consumers.

Based on all these insights we decided to create a framework which could possibly integrate decisions related to inventory across central and store management teams. The new framework essentially consists of; 
5.1 Product categorization by need: Every category/brand/product has a role to play with respect to consumer needs and retailers business goals. Based on demand side characteristics all the categories/brands/products in the assortment were classified into essentials and non-essentials. Essential category consists of products which are required by the consumers at least once in a month and non-essentials products are the ones which do not fulfil the essential category criteria. This categorization was not dependent on any supply side constraints.

5.2 Product categorization by characteristics: Every product has its own characteristics and the same changes over a period of time owing to changes in (a) style/colour/trend, (b) season and (c) technology or due to (a) upgradation, (b) added features and (c) modified dimensions. In addition to these factors, there might be many other factors which directly or indirectly vary the product characteristic. Usually, every variation accompanies with a change in the unique identity number of products which is known as either Universal Product Code (UPC) or European Article Number (EAN) or any other identity code which is unique for a particular product. The level of variability of a product's characteristics are different for different product groups or categories and based on this level we categorized each product into (a) low, (b) medium and (c) high. Products falling under low variability category are the ones which retain their unique identity number at least for a period of twelve months, products under medium variability level are the ones which are modified at least once in six months and products with high variability are the once which are required to be modified/changed at least once in three months.

5.3 Control systems: We had enough evidence on pros and cons of various inventory management control systems through existing systems, experiments and available literature and based these evidence we categorized control systems into (a) centralized which is completely controlled by central management teams, (b) decentralized which is completely controlled by store team and (c) automatic replenishment system which is controlled by systems wherein the store product requirements are calculated automatically by the system based on actual sales, existing inventory levels and minimum inventory level set for a particular product and store.

5.4 Control mechanisms: It is important to have an appropriate control mechanism with respect to inventory related decision-making process. Key aspects which are important in creating a brand image and positioning in consumers mind such as (a) type of brands, (b) quality of products and (c) product pricing in the assortment. A clear guideline was made available to all the central and store management teams on the list of allowed and restricted categories/products/brands/prices which would enable the retailer to overcome any decision bias. All the financial measures such as (a) target stock cover, (b) target inventory turn, (c) minimum product level intake margins and (d) threshold for purchase values were also set and were rigorously monitored/controlled by the central finance team. Based on the key components (a) product category and (b) variability level in product characteristics we created a new inventory management control framework as shown in framework 1 .

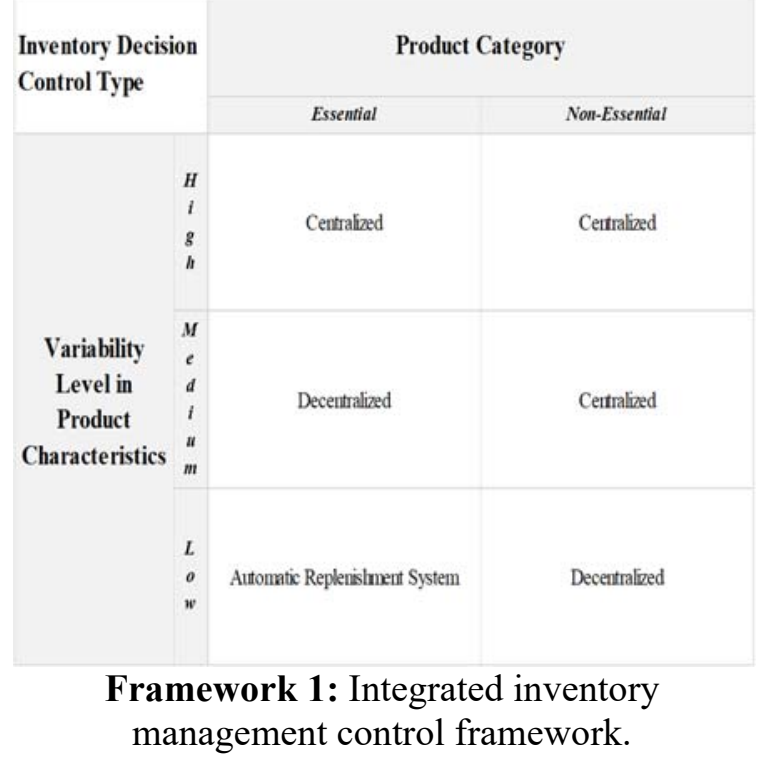

The new integrated inventory management control system framework was applied (experiment 2) in select stores for a period of three months to evaluate its implications on overall store profitability.

6. KEY FINDINGS AND INSIGHTS : 
Using Solomon's four-group real treatment effect formula, we have found that the real treatment effect has shown an84.55 times improvement in the overall store profitability of the experimental group over their pre-test period. Comparative results as shown in table 1, 2,3 and 4when compared with different types of inventory management indicate that in the experimental group of stores application of new framework has shown an increase in the purchase of essential products by 122 percent over centralized inventory management system and 68 percent increase in the purchase of essential products over decentralized inventory management system which in turn has shown 86.38 times improvement in overall store profitability over centralized and 2.45 times improvement over decentralized inventory management systems. In the experimental group, inventory turns increased from 2.28 to 3.77 which is a 65.21 percent increase over centralized inventory management system, whereas in the control group the inventory turns marginally increased from 2.05 to 2.40 which is a 16.87 percent increase. Results also indicate that the correlation between purchase of essential products and overall store revenue is positive at 0.501 with an adjusted $R$ square value of 0.204 , the correlation between purchase of non-essential products and overall store revenue is negative at -0.303 with an adjusted $\mathrm{R}$ square value of 0.035 and the correlation between overall purchase value and overall store revenue is negative at -0.066 with an adjusted $\mathrm{R}$ square value of -0.058 . We have found a significant positive association and determination between the purchase of essential products and overall store profitability with a ttest 2-tailed sig. value of 0.000 .

Table 3: Percentage change over centralized inventory management across key factors in decentralized inventory management for control and experimental.

\begin{tabular}{|c|c|c|}
\hline \multirow[b]{2}{*}{ Factors } & \multicolumn{2}{|c|}{ Decentralized Decentralized } \\
\hline & $\begin{array}{l}\text { Control } \\
\text { Group }\end{array}$ & $\begin{array}{l}\text { Experimental } \\
\text { Group }\end{array}$ \\
\hline Purchase vahe per day per square foot - Essentials & $.5 \%$ & $32 \%$ \\
\hline Purchase vahe per day per square foot - Non-Essentials & $42 \%$ & $55 \%$ \\
\hline Average MRP of store & $12 \%$ & $17 \%$ \\
\hline Average selling price of store & $1 \%$ & $1 \%$ \\
\hline Average transaction vahue of store & $1 \%$ & $1 \%$ \\
\hline Average basket szie of store & $0 \%$ & $0 \%$ \\
\hline Discount per cent & $.9 \%$ & $.7 \%$ \\
\hline Purchase vahe per day per square foot & $29 \%$ & $49 \%$ \\
\hline Bills per day per square foot & $-13 \%$ & $8 \%$ \\
\hline Sale quantitity per day per square foot & $-12 \%$ & $8 \%$ \\
\hline Discount vahue per day per square foot & $.7 \%$ & $22 \%$ \\
\hline Reventue per day per square foot & $-11 \%$ & $9 \%$ \\
\hline Eaming per day per square foot & $4 \%$ & $27 \%$ \\
\hline Profit per day per square foot & $86 \%$ & $-3625 \%$ \\
\hline
\end{tabular}

As far as qualitative findings are concerned an open-ended interview was conducted with all the sales personnel of the stores under experimental group post-test and unanimously, they have all said, (a) number of instances of loss of sales was reduced drastically, (b) store was carrying products which were relevant to their catchment, (c) focus on the store relevant requirement was high, (d) piling up of stocks which were not relevant to store reduced drastically and most importantly (e) the control level in product ordering was high. Another key insight from these direct interviews was that the results of this experiment were clearly visible to them as they were able to get many of these consumers to return to their store more frequently which helped them to earn significantly higher incentives as compared to periods wherein other inventory management systems were in effect.

Table 4: Percentage change over centralized inventory management across key factors in an integrated inventory management framework for control and experimental. 


\begin{tabular}{|l|c|c|}
\hline Factors & $\begin{array}{c}\text { Integrated } \\
\text { Framework } \\
\text { Control } \\
\text { Group }\end{array}$ & $\begin{array}{c}\text { Integrated } \\
\text { Framework } \\
\text { Experimental } \\
\text { Gloup }\end{array}$ \\
\hline Purchase vahe per day per square foot - Essentials & $58 \%$ & $122 \%$ \\
\hline Purchase vahue per day per square foot - Non-Essentials & $18 \%$ & $49 \%$ \\
\hline Average MRP of store & $-2 \%$ & $0 \%$ \\
\hline Average selling price of store & $0 \%$ & $-2 \%$ \\
\hline Average transaction value of store & $-4 \%$ & $-10 \%$ \\
\hline Average basket size of store & $-3 \%$ & $-8 \%$ \\
\hline Discount per cent & $-15 \%$ & $19 \%$ \\
\hline Purchase vahue per day per square foot & $29 \%$ & $69 \%$ \\
\hline Bills per day per square foot & $46 \%$ & $75 \%$ \\
\hline Sale quantity per day per square foot & $41 \%$ & $60 \%$ \\
\hline Discount vahte per day per square foot & $16 \%$ & $90 \%$ \\
\hline Revemte per day per square foot & $41 \%$ & $58 \%$ \\
\hline Eaming per day per square foot & $95 \%$ & $97 \%$ \\
\hline Profit per day per square foot & $105 \%$ & $8538 \%$ \\
\hline
\end{tabular}

Table 5: Percentage change over decentralized inventory management across key factors in an integrated inventory management framework for control and experimental.

\begin{tabular}{|l|c|c|}
\hline Factors & $\begin{array}{c}\text { Integrated } \\
\text { Frame work } \\
\text { Control } \\
\text { Group }\end{array}$ & $\begin{array}{c}\text { Integrated } \\
\text { Framework } \\
\text { Experimental } \\
\text { Group }\end{array}$ \\
\hline Purchase vahre per day per square foot - Essentials & $66 \%$ & $68 \%$ \\
\hline Purchase value per day per square foot - Non-Essentiak & $-17 \%$ & $-4 \%$ \\
\hline Average MRP of store & $-13 \%$ & $-15 \%$ \\
\hline Average selling price of store & $-1 \%$ & $-2 \%$ \\
\hline Average transaction value of store & $-5 \%$ & $-10 \%$ \\
\hline Average basket size of store & $-4 \%$ & $-8 \%$ \\
\hline Discount per cent & $-7 \%$ & $28 \%$ \\
\hline Purchase value per day per square foot & $0 \%$ & $14 \%$ \\
\hline Bills per day per square foot & $67 \%$ & $61 \%$ \\
\hline Sale quantity per day per square foot & $60 \%$ & $48 \%$ \\
\hline Discomt vahte per day per square foot & $25 \%$ & $56 \%$ \\
\hline Revemte per day per square foot & $59 \%$ & $45 \%$ \\
\hline Eaming per day per square foot & $88 \%$ & $55 \%$ \\
\hline Profit per day per square foot & $103 \%$ & $345 \%$ \\
\hline
\end{tabular}

Table 6: Percentage change in the experimental group over the control group across key factors

in an integrated inventory management framework.

\begin{tabular}{|l|c|}
\hline Factors & $\begin{array}{c}\text { Integrated } \\
\text { Framework } \\
\text { Experimental } \\
\text { Group }\end{array}$ \\
\hline Purchase vahue per day per square foot - Essentials & $37 \%$ \\
\hline Purchase vahue per day per square foot - Non-Essentials & $24 \%$ \\
\hline Average MRP of store & $-3 \%$ \\
\hline Average selling price of store & $-3 \%$ \\
\hline Average transaction value of store & $-11 \%$ \\
\hline Average basket size of store & $-8 \%$ \\
\hline Discount per cent & $8 \%$ \\
\hline Purchase vahue per day per square foot & $28 \%$ \\
\hline Bills per day per square foot & $38 \%$ \\
\hline Sale quantity per day per square foot & $28 \%$ \\
\hline Discount value per day per square foot & $34 \%$ \\
\hline Reventue per day per square foot & $23 \%$ \\
\hline Earning per day per square foot & $24 \%$ \\
\hline Profit per day per square foot & $2951 \%$ \\
\hline
\end{tabular}

\section{CONCLUSION :}

Inventory is a complex component of selling proposition and makes the purchasing phenomenon furthermore complicated to understand. It is not just about mathematically/strategically setting the ideal (a) level of the purchase value, (b) timing of purchase, (c) frequency of purchase, (d) stock cover, (e) inventory turns, (f) controller of purchase, and (g) minimum sales (actual, forecasted or budgeted) threshold to derive the purchase value, it is imperative to set limitations on (a) understanding the role of every product/category and consumers in relation to the overall business goal of the retailing format, (b) what type of product to purchase, (c) purchase frequency based on product type and most importantly,(d) who is the right person to decide on purchasing what, when and how much is required for the store. The integrated inventory management framework experimented has taken all these complexities and limitations into consideration while also ensuring appropriate financial control mechanisms being recommended to avoid any misuse of the new system by sales personnel. The experiment of applying integrated inventory management framework has shown a significant improvement across various key performance indicators such as;(a) conversion,(b) sales quantity, (c) revenue, 
(d) gross margin value, (e) store profitability, (f) inventory turns, (g) cash-flow management and most importantly, (h) reduction in number instances of loss of sales. It was evident from the experimentation results that, even though the overall purchase value in the experimental group had increased by 1.284 times in comparison to the control group, the overall store profit of experimental group stores had shown 30.507 times improvement over the control group stores. Brick-and-mortar retailers need to understand that the sales personnel are the ambassadors of the store/brand who are directly connected with the consumers on a real-time basis which help them understand the inventory requirement relevant to their consumers and a centrally supervised decentralization of inventory management could possibly reduce the number of instances consumers are unsatisfied due to unavailability of relevant stocks thereby influencing the retailer/brand/store image in consumers mind as far as their long-term association with the retailer/brand/store is concerned.

\section{SUGGESTIONS TO BRICK-AND- MORTAR RETAILERS:}

Based on this research outcome, we would like to suggest Brick-and-mortar retailers that they need to clearly understand the role of every product/category/brand in relation to consumers and long-term business goals. Do not look at the store management team as resources for just managing store operations and handling consumer queries, rather, involve them in inventory management decisions on a regular basis. Obviously a complete authority of inventory management cannot be given to store management team, but with rigorous monitoring systems in place being supervised by the central category, retail planning, supply chain and finance teams could possibly help in purchasing relevant inventory at right time in the right quantity and frequency thereby improving cashflow management, overall store profitability, and most importantly consumer satisfaction level.

\section{LIMITATIONS OF RESEARCH:}

The main limitation of this research work is the coverage of various stakeholders viz., consumers, and retailers in experimenting with this new framework. This might limit the generalizability of the research findings to other set of retailers and consumers. The second limitation would be the empirical validation is restricted to one retail format i.e., multi brand and multi category baby care stores in India and hence the generalizability of the findings and suggestions to other retail formats. The third limitation would be our ability to carry out true experimental design, at best we were able to carry out a Solomon four-group experimental design. However, it provides significant input regarding the ways to utilise these findings as all the findings have been derived from an experiment spread over three months.

\section{SCOPE FOR FURTHER RESEARCH:}

It is recommended that the proposed framework to be experimented by researchers and finetune the framework if required for different retailing formats and verticals. Based on the key growth objectives for a specific period and specific context, brick-and-mortar retailers can implement this framework at their select stores and finetune the same based on real-time findings which can then be implemented across the entire chain of their stores.

\section{REFERENCES:}

[1] Salmon, W. J. (1989). Retailing in the age of execution. Journal of Retailing, 65(3), 368378.

[2] Raman, A., N. DeHoratius and Z. Ton. (2001). Execution: the missing link in retail operations. California Management Review, 43(3), 136-142.

[3] Wagner, H.M. (2002). And then there were none. Operations Research. 50(1) 217-227.

[4] Keizers, J. M., J. W. M. Bertrand, J. Wessels. (2003). Diagnosing Order Planning Performance at a Navy Maintenance and Repair Organization using Logistic Regression. Production and Operations Management, 12(4) 445-464.

[5] Corsten, D. and T. Gruen. (2003). Seeking on-shelf availability - an examination of the 
extent, the causes and the efforts to address retail out-of-stocks. International Journal of Retail and Distribution Management, 31(12), 605-716.

[6] DeHoratius, N. and A. Raman. (2003). Building on foundations of sand? ECR Journal, 3(1), 62-63.

[7] Ton, Z. and A. Raman. (2004). The effect of product variety and inventory levels on retail store operations: a longitudinal study. Harvard University.

[8] Van Donselaar, K. H., V. Gaur, T. van Woensel, R. A. C. M. Broekmeulen and J. C. Fransoo. (2006). An empirical study of ordering behavior of retail stores. Working paper, Eindhoven University of Technology.

[9] James L. Heskett, W. Earl Sasser, Leonard Schlesinger The Service Profit Chain: How Leading Companies Link Profit and Growth to Loyalty, Satisfaction, and Value. New York: The Free Press, 1997.

[10]Davis, H. L., \& Silk, A. J. (1972). Interaction and influence processes in personal selling. Sloan Management Review (Pre-1986), 13(2), 59.

[11]Dawson, Lyndon E. Jr, Soper, B., \& Pettijohn, C. E. (1992). The effects of empathy on salesperson effectiveness. Psychology \& Marketing (1986-1998), 9(4), 297

[12] Sharma, A. (2001). Consumer decisionmaking, salespeople's adaptive selling and retail performance. Journal of Business Research, 54(2), 125-129.

[13]Pettijohn, C. E., Pettijohn, L. S., \& Taylor, A. J. (2002). The influence of salesperson skill, motivation, and training on the practice of customer-oriented selling. Psychology \& Marketing, 19(9), 743-757.

[14]Davis, D. D. (2008). The influence of salesperson leadership as a customer interaction behavior on sales performance. Nova Southeastern University.

[15] Singh, S., Marinova, D., Singh, J., \& Evans, K. R. (2018). Customer query handling in sales interactions. Journal of the Academy of Marketing Science, 46(5), 837-856.

[16] Ganesha, H. R., Aithal, P. S., \& Kirubadevi, P. (2020). Input and Output Driven Sales Personnel Performance Measures: Insights from an Experiment. International Journal of Case Studies in Business, IT, and Education (IJCSBE), 4(1), 23-37. DOI: http://doi.org/10.5281/zenodo.3764555.

[17] Ganesha, H. R., Aithal, P. S., \& Kirubadevi, P. (2020). Decentralized Discounting Framework: Insights from an Experiment. International Journal of Applied Engineering and Management Letters (IJAEML), 4(1), 2040.

DOI: http://doi.org/10.5281/zenodo.3762879.

[18] Ganesha, H. R., Aithal, P. S., \& Kirubadevi, P. (2020). Need-Based Sales Pitch: Insights from an Experiment: Insights from an Experiment. International Journal of Case Studies in Business, IT, and Education (IJCSBE), 4(1), 78-86. DOI: http://doi.org/10.5281/zenodo.3766912.

$* * * * * * *$ 